\title{
Preliminary Screening for Microplastic Concentrations in the Surface Water of the Ob and Tom Rivers in Siberia, Russia
}

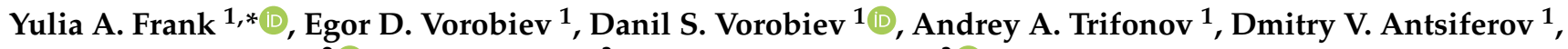 \\ Tina Soliman Hunter ${ }^{2}$ D, Scott P. Wilson ${ }^{3}$ and Vladimir Strezov ${ }^{3} \mathbb{D}$ \\ 1 Biological Institute, National Research Tomsk State University, Lenina Ave., 36, 634050 Tomsk, Russia; \\ vorobievegor@gmail.com (E.D.V.); danilvorobiev@yandex.ru (D.S.V.); packtrif@mail.ru (A.A.T.); \\ dmitry.antsiferov@gmail.com (D.V.A.) \\ 2 Macquarie Law School, Macquarie University, Sydney, NSW 2109, Australia; tina.solimanhunter@mq.edu.au \\ 3 Department of Earth and Environmental Sciences, Faculty of Science and Engineering, Macquarie University, \\ Sydney, NSW 2109, Australia; scott.p.wilson@mq.edu.au (S.P.W.); vladimir.strezov@mq.edu.au (V.S.) \\ * Correspondence: yulia.a.frank@gmail.com
}

Citation: Frank, Y.A.; Vorobiev, E.D.; Vorobiev, D.S.; Trifonov, A.A.;

Antsiferov, D.V.; Soliman Hunter, T.; Wilson, S.P.; Strezov, V. Preliminary Screening for Microplastic Concentrations in the Surface Water of the $\mathrm{Ob}$ and Tom Rivers in Siberia, Russia. Sustainability 2021, 13, 80 https://dx.doi.org/10.3390/su13010080

Received: 14 November 2020 Accepted: 20 December 2020 Published: 23 December 2020

Publisher's Note: MDPI stays neutral with regard to jurisdictional claims in published maps and institutional affiliations.

Copyright: () 2020 by the authors. Licensee MDPI, Basel, Switzerland. This article is an open access article distributed under the terms and conditions of the Creative Commons Attribution (CC BY) license (https: / / creativecommons.org/ licenses/by/4.0/).

\begin{abstract}
To date, the largest Russian rivers discharging to the Arctic Ocean remain a "blank spot" on the world map of data on the distribution of microplastics in freshwater systems. This study characterizes the abundance and morphology of microplastics in surface water of the Ob River and its large tributary, the Tom River, in western Siberia. The average number of particles for the two rivers ranged from 44.2 to 51.2 items per $\mathrm{m}^{3}$ or from 79.4 to $87.5 \mu \mathrm{g}$ per $\mathrm{m}^{3}$ in the Tom River and in the $\mathrm{Ob}$ River, respectively. Of the recovered microplastics, $93.5 \%$ were less than $1 \mathrm{~mm}$ in their largest dimension, the largest group ( $45.5 \%$ of total counts) consisted of particles with sizes range 0.30-1.00 mm. Generally, microfragments of irregular shape were the most abundant among the $\mathrm{Ob}$ and Tom samples (47.4\%) and exceeded microfibers (22.1\%), microfilms (20.8\%), and microspheres $(9.74 \%)$ by average counts. Results from this study provide a baseline for understanding the scale of the transport of microplastics by the Ob River system into the Arctic Ocean and add to currently available data on microplastics abundance and diversity in freshwater systems of differing global geographic locations.
\end{abstract}

Keywords: microplastic abundance; microplastic cycle; freshwater; rivers

\section{Introduction}

Microplastics (MPs) are a collective term to describe any synthetic solid particle or polymeric matrix with regular or irregular shape and with size under $5 \mathrm{~mm}$ [1]. Typically, particles less than $1 \mathrm{~mm}$ are classified as MPs, while those larger than $1 \mathrm{~mm}$ (up to 25-100 mm) are referred to as mesoplastics [2,3]. Small particles are formed in the process of sequential decomposition of larger plastic materials mainly resulting from the action of physical and chemical factors [4] or can enter aquatic systems in the form of small pellets or beads used in many industrial processes and personal care products [5]. The main reason for concern about microplastic (MP) water pollution is its ecotoxicological effects on hydrobionts, and potential transference and toxicity through the food chain to humans [6-11]. MP particles can adsorb toxic chemicals, serving as vectors of their transport into ecosystems. Some plastics may contain hazardous chemicals added during their production to improve polymer properties [8,12].

Previous studies primarily considered MPs as an ocean problem, while in recent years MPs have been detected in freshwater [13,14], groundwater [15], soils [16,17], terrestrial biota [18], snow [19], and the atmosphere [20,21]. The transportation and transformation of MPs between planetary compartments have been depicted as a "microplastic cycle" [22], with surface ocean currents considered to be the key mechanism for the global transport of MPs [23]. 
Freshwater streams are also likely to be important transportation pathways for MPs [22,24,25]. Accumulation of plastic debris in continental freshwater systems has become a subject of research in recent times [12,13,26-28]. Knowledge of MP abundance in freshwater aquatic systems, including rivers, remains limited, making data retrieval a difficult task [29]. However, it is clear that the volume of MPs carried by rivers is in the order of tens and hundreds of tons, as estimated for the large European rivers including the Rhine, the Danube, and the Po [30].

Northern-flowing rivers may be primary freshwater sources of MPs to the Arctic Ocean. The largest Eurasian Arctic rivers are the Pechora, Severnaya Dvina, Ob, Yenisey, Lena, and Kolyma rivers [31]. The $\mathrm{Ob}$ River is one of the largest rivers discharging to the Arctic Ocean in terms of watershed area, with its annual discharge accounting for $8 \%$ of the total freshwater inflow to the Arctic Ocean [32]. Located in Western Siberia, the $\mathrm{Ob}$ River, along with its major tributary the Irtysh River, have a combined length of $3650 \mathrm{~km}$, and almost 3 million square kilometers watershed area. The $\mathrm{Ob}$ flows from the Altay Mountains of Inner Asia into the Arctic Ocean with direct input into the Kara Sea [33]. The level of contribution of Siberian rivers to the MP pool in the Arctic region remains uncertain. Considering the significant and longstanding human habitat and industrial activities in Siberia, an understanding of MP discharge from this region to the Arctic is important in establishing a better understanding of the Arctic environment and enabling greater control of MP influx into the region.

The aim of the current research is to evaluate the abundance of MPs in the Ob River system in its middle course, as a potential indicator of MP transport from the western Siberian region to the Arctic Ocean.

\section{Materials and Methods}

\subsection{Study Area}

Surface water was sampled from the $\mathrm{Ob}$ River $(n=5)$, and the Ob tributary, the Tom River $(n=4)$. Water samples were collected in the upper and middle Ob River near Mochische village, downstream Novosibirsk (site 1-O) and inhabited localities in the Tomsk region: Krasnyj Yar (2-O), Pobeda (3-O), Kolpashevo (4-O), and Kargasok (5-O) (Figure 1). Water from the Tom River was sampled near Moszhukha, downstream Kemerovo (1-T), in Yurga, Kemerovo region (2-T), Medvedka village, Tomsk region (3-T), and near Tomsk (4-T) (Figure 1). The geographical coordinates of each sampling site are indicated in Table 1.

The study area was mostly confined to the southern part of the West Siberian Plain. The West Siberian Plain geologically has three main structural levels: (1) folded basement made by formations of almost exclusively Paleozoic age; (2) rift (or intermediate) structural level represented by basalts, sometimes by basalts and rhyolites of the early Triassic age, which are replaced upward in the section by the terrigenous depth of middle and late Triassic age; and (3) orthoplatform cover, composed mostly of Jurassic rocks [34]. To the south, the Mesozoic-Tertiary sediment gradually thins and pinches out toward the Central Kazakhstan and Altay-Sayan folded regions [35].

At the sampling sites, the Ob River (length $3650 \mathrm{~km}$, and drainage area 2,990,000 $\mathrm{km}^{2}$ ) is about $750-800 \mathrm{~m}$ wide and has an average depth of $3 \mathrm{~m}$. The Tom River (length $827 \mathrm{~km}$ and drainage area $62,000 \mathrm{~m}^{2}$ ) at the sampling sites has a width of approximately $200 \mathrm{~m}$ and an average depth of $2.5 \mathrm{~m}$.

A population of 4.133 million people live in the catchment area of the two rivers [36]. Considering that large industrial centers of West Siberia occupy the upstream areas and along the two rivers, there are many potential point sources of pollution, including businesses, factories, and water treatment plants related to the cities of Biysk, Barnaul, and Novosibirsk (Ob River), and Novokuznetsk, Kemerovo, and Tomsk (Tom River). More northerly areas, such as Kolpashevo and Kargasok in the Tomsk region, are fishing centers, and are sources of fishing tackle that contribute MPs. For these reasons, the surveyed waters were expected to be contaminated with MP. 


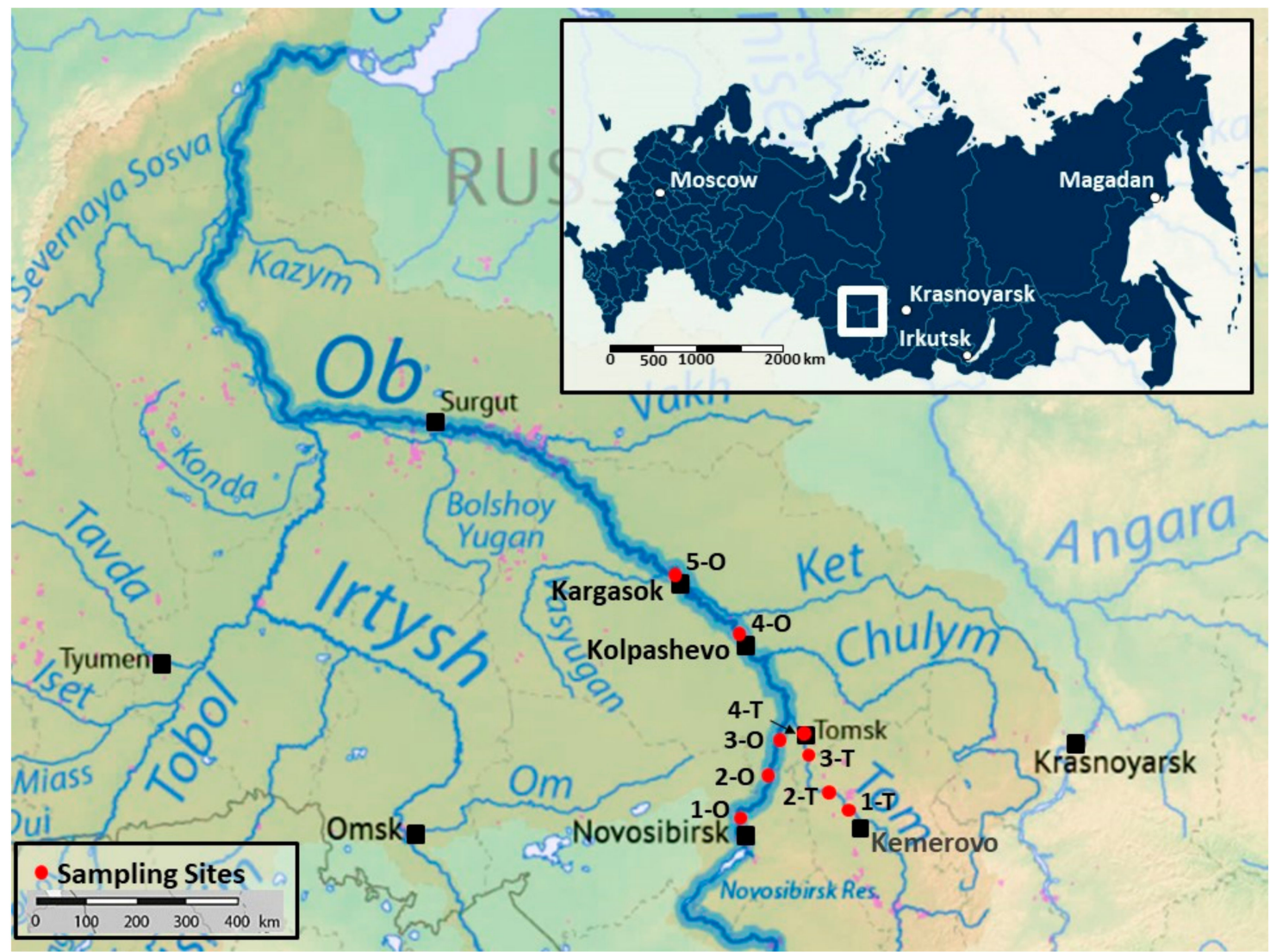

Figure 1. Location map of surface water collected for analysis of microplastic (MP) abundance. Catchment area boundaries are marked with a white square on the top map.

Table 1. Location of the sampling sites.

\begin{tabular}{|c|c|c|c|c|c|c|c|c|c|}
\hline Sampling Sites & $1-\mathrm{T}$ & 2-T & 3-T & $4-\mathrm{T}$ & $1-O$ & $2-\mathrm{O}$ & $3-\mathrm{O}$ & 4-O & $5-\mathrm{O}$ \\
\hline $\begin{array}{l}\text { Geographical } \\
\text { coordinates }\end{array}$ & $\begin{array}{l}55^{\circ} 25^{\prime} 31.188^{\prime \prime} \mathrm{N} \\
85^{\circ} 55^{\prime} 24.960^{\prime \prime} \mathrm{E}\end{array}$ & $\begin{array}{l}55^{\circ} 44^{\prime} 13.344^{\prime \prime} \mathrm{N} \\
84^{\circ} 56^{\prime} 28.140^{\prime \prime} \mathrm{E}\end{array}$ & $\begin{array}{l}56^{\circ} 10^{\prime} 53.472^{\prime \prime} \mathrm{N} \\
84^{\circ} 52^{\prime} 44.760^{\prime \prime} \mathrm{E}\end{array}$ & $\begin{array}{c}56^{\circ} 26^{\prime} 56.724^{\prime \prime} \mathrm{N} \\
84^{5} 56^{\prime} 8196^{\prime \prime} \mathrm{E}\end{array}$ & $\begin{array}{l}55^{\circ} 11^{\prime} 6972^{\prime \prime} \mathrm{N} \\
82^{\circ} 52^{\prime} 57.396^{\prime \prime} \mathrm{E}\end{array}$ & $\begin{array}{l}56^{\circ} 4^{\prime} 42.348^{\prime \prime} \mathrm{N} \\
83^{\circ} 51^{\prime} 47.484^{\prime \prime} \mathrm{E}\end{array}$ & $\begin{array}{l}56^{\circ} 31^{\prime} 48.468^{\prime \prime} \mathrm{N} \\
84^{\circ} 9^{\prime} 40.824^{\prime \prime} \mathrm{E}\end{array}$ & $\begin{array}{l}58^{\circ} 18^{\prime} 16.416^{\prime \prime} \mathrm{N} \\
82^{\circ} 54^{\prime} 27.864^{\prime \prime} \mathrm{E}\end{array}$ & $\begin{array}{c}59^{\circ} 4^{\prime} 1992^{\prime \prime} \mathrm{N} \\
80^{\circ} 50^{\prime} 58.668^{\prime \prime} \mathrm{E}\end{array}$ \\
\hline
\end{tabular}

\subsection{Sampling and Field Studies}

All sites were sampled in the period from 15 June to 25 June 2020. According to recommendations for riverine environments [37], sampling was performed on the surface of the water, since many of the MPs should float on freshwater $\left(1.00 \mathrm{~g} \mathrm{~cm}^{-3}\right)$ surface as a result of the minimal size, weight, and relative density of the materials [37]. It is acknowledged that some types of MPs such as nylon-6, polyethylene terephthalate, and polyvinyl chloride may sink due to higher density, having a density greater than $1.00 \mathrm{~g} \mathrm{~cm}^{-3}$, and may be partly lost [38]. A Manta trawl was custom designed and constructed for the survey using a standard template with a $0.33 \mathrm{~mm}$ mesh net. It was placed in the direction of flow and fixed at a water depth of 1.3-1.5 m for 20 to 30 min to collect plastic particles floating in the water top layer (Figure S1). The trawl was designed to capture floating particles to a depth of $15 \mathrm{~cm}$. All samples were collected in triplicates (three individual samples were taken at the same site, using the same Manta trawl installed in the same fixed position).

Temperature, $\mathrm{pH}$, and oxidation-reduction potential (Eh) of the river water at sample sites were determined using a portable $\mathrm{pH} / \mathrm{mV} /{ }^{\circ} \mathrm{C}$ meter $\mathrm{HI} 8314$ from Hanna Instruments. Flow rate was determined using the time and distance method of a floating object (Water Management Manual, 2001) [39]. The results of the triplicate measurements were averaged.

For chemical analysis, the samples were filtered through a $0.45 \mu \mathrm{m}$ membrane filter, collected in sterile $50 \mathrm{~mL}$ plastic tubes and stored at $4{ }^{\circ} \mathrm{C}$ before analysis, as recommended by Fernández-Turiel et al. [40]. Elemental analysis of the water was carried out 
by inductively coupled plasma mass spectrometry (ICP-MS) at the "Plasma" chemical analytic center (Tomsk, Russia) utilizing the processing procedure described by Pokrovsky and Shirokova [41].

\subsection{Laboratory Analysis of Microplastics}

Microplastics were extracted from total water samples by sieving and dense-liquid separation by slightly modified U.S. National Oceanic and Atmospheric Administration (NOAA) protocol [42]. The analysis included four main steps: (1) sequential sieving, (2) wet peroxide oxidation, (3) density separation, and (4) MP detection. Samples were first run through 5-mm and 0.33-mm sieves and thoroughly washed with distilled water. The collected fraction was subjected to further treatments. Organic material was digested using wet peroxide oxidation ( $0.05 \mathrm{M} \mathrm{Fe}$ (II) and $30 \%$ hydrogen peroxide) at $\sim 70{ }^{\circ} \mathrm{C}$ on a water bath. The procedure was repeated twice to remove all organics from the samples. In order to separate plastics from mineral particles, density separation was performed in $1.19 \mathrm{~g} / \mathrm{mL} \mathrm{NaCl}$ solution overnight in a separating funnel. Particles were collected on the painted membrane $0.45 \mu \mathrm{m}$ filters (Sartorius, GmbH, Germany). Total mass of the MP particles in each sample was measured by gravimetric analysis of plastic material collected on the membrane filter. MPs were then counted under a dissecting microscope (stereomicroscope Micromed MC2 equipped with digital camera and ToupView 3.7.6273 software, version 3.7), using the physical characteristics of MP particles as previously described by McCormick et al. [43]. Due to the pilot nature of this study, no polymer analysis was conducted. The MP concentrations were normalized per cubic meter by multiplying the exposure time by the current velocity and the Manta trawl cross section area.

To prevent sample contamination, all materials and implements used were either glass (glassware) or stainless steel (instruments) wherever possible, and the laboratory and field clothes were made of cotton. To ensure absence of contamination in the process of sample preparation, replicated $(n=3)$ procedural blanks (negative controls) were analyzed, as recommended by Koelmans et al. [44].

\subsection{Processing of the Results}

The extracted MP particles were classified into four groups by shape: (1) microfragments, (2) microfilms, (3) microspheres, and (4) microfibers [1]. The MP particles were further classified into seven groups by their major dimension: (1) $<0.15 \mathrm{~mm},(2) 0.15-0.30$ $\mathrm{mm}$, (3) $0.30-1.00 \mathrm{~mm}$, (4) $1.00-2.00 \mathrm{~mm}$, (5) $2.00-3.00 \mathrm{~mm}$, (6) $3.00-4.00 \mathrm{~mm}$, and (7) 4.00-5.00 $\mathrm{mm}$. Particle dimensions were measured by ToupView 3.7.6273.

The percent composition by number of MP shapes and sizes was determined using the following equation:

$$
\text { Composition }(\%)=\left(\mathrm{C}_{\mathrm{mp}} / n\right) \times 100
$$

where $\mathrm{C}_{\mathrm{mp}}$ is the number of MP particles of a given shape or size, and $n$ is the total number of MP in the sample.

MP abundance was evaluated both as the number of MP particles and their total mass per $1 \mathrm{~m}^{3}$ for each sampling site. Sample processing and MP detection were performed in parallel from three independent samples. The arithmetic mean and standard deviation of the mean were calculated from the data obtained.

The average MP concentration and mass in the water (top $15 \mathrm{~cm}$ layer) of the studied rivers was determined through the calculation of the arithmetic mean of all samples. The Mann-Whitney U test [45] was used to compare differences in total MP counts and mass between two rivers, and to compare abundance of different MP shape types between sites. The non-parametric Kruskal-Wallis H test [46] was utilized to compare differences in total MP counts and mass between the $\mathrm{Ob}$ and Tom rivers. Results were considered statistically significant at $p \leq 0.05$. 


\section{Results}

\subsection{Physico-Chemical Characteristic of the Water}

Water in the $\mathrm{Ob}$ and Tom rivers was characterized mostly as alkaline, with a tendency to decrease in $\mathrm{pH}$ northwards (Table 2). At the 4-T sampling site (the northernmost point on the Tom) and 5-O sampling site (the most northern point on the tested Ob sites), the $\mathrm{pH}$ was circumneutral (close to 7.5). This may be linked to changes in geomorphological conditions and the soil composition towards the north. The comparably high $\mathrm{pH}$ of the $\mathrm{Ob}$ River system water is associated with groundwater feeding [47].

Table 2. Physico-chemical characteristics of the water.

\begin{tabular}{cccccccccc}
\hline Sampling Sites & $\mathbf{1 - T}$ & 2-T & 3-T & 4-T & 1-O & 2-O & 3-O & 4-O & 5-O \\
\hline $\mathrm{pH}$ & 8.19 & 8.85 & 8.60 & 7.55 & 8.23 & 8.81 & 8.82 & 7.96 & 7.49 \\
$\mathrm{~T},{ }^{\circ} \mathrm{C}$ & 15.7 & 17.2 & 15.5 & 19.6 & 18.4 & 20.0 & 19.9 & 18.9 & 18.4 \\
$\mathrm{Eh}, \mathrm{mV}$ & +248 & +272 & +268 & +243 & +263 & +181 & +201 & +207 & +218 \\
\hline
\end{tabular}

The water temperature during the sampling period in June 2020 did not exceed $20^{\circ} \mathrm{C}$. The redox potential of the water varied from 181 to $272 \mathrm{mV}$ characterizing redox conditions as moderately oxidized since in well-oxidized water, as long as oxygen concentrations stay above $1 \mathrm{mg} \mathrm{O}_{2} \mathrm{~L}^{-1}$, the Eh will be above $300-500 \mathrm{mV}$ [48].

Table 3 presents the elemental composition of the $\mathrm{Ob}$ and Tom rivers water. The concentration of most elements were below the detection limit, therefore only elements with detectable concentration are presented in this table. As can be seen in Table 3, the first group of elements presented $(\mathrm{Na}, \mathrm{Mg}, \mathrm{K}, \mathrm{Ca}, \mathrm{Si}$, and $\mathrm{Fe}$ ) have concentrations measured in milligrams per $\mathrm{L}\left(\mathrm{mg} \mathrm{L}^{-1}\right)$. The Ob River water in the southernmost sample site (1-O) was the richest in $\mathrm{Na}$ and $\mathrm{Mg}$ compared to Tom water and water from the more northern parts of the $\mathrm{Ob}$ River.

The range of metal concentrations $\left(<0.10-0.22 \mu g \mathrm{~L}^{-1}\right.$ for $\mathrm{Co},<0.10-2.60 \mu \mathrm{g} \mathrm{L}{ }^{-1}$ for $\mathrm{Ni},<0.10-1.60 \mu \mathrm{g} \mathrm{L}{ }^{-1}$ for $\mathrm{Cu}$, and $<0.10-3.20 \mu \mathrm{g} \mathrm{L}^{-1}$ for $\mathrm{Zn}$ ) were in the same range as a previously reported study undertaken in the middle $\mathrm{Ob}$ [47]. Other elements detected in micrograms per $\mathrm{L}\left(\mu \mathrm{g} \mathrm{L}^{-1}\right.$ ) were (in descending order) $\mathrm{Sr}, \mathrm{Ba}, \mathrm{Mn}, \mathrm{Al}, \mathrm{P}, \mathrm{Li}, \mathrm{V}, \mathrm{As}, \mathrm{Mo}, \mathrm{U}$, $\mathrm{Rb}$, and $\mathrm{Sb}$ (Table 3). Rare earth elements as $\mathrm{Y}, \mathrm{La}, \mathrm{Ce}$, and $\mathrm{Nd}$ were detected in sample site 5-O.

Mobile elements, such as cations ( $\mathrm{Na}, \mathrm{K}, \mathrm{Mg}$, and $\mathrm{Ca}$ ), alkaline earth traces $(\mathrm{Sr})$, trace oxyanions (Mo and $\mathrm{Sb}$ ), and $\mathrm{U}$, marked the influence of underground feeding of the rivers in summer. As shown earlier, the majority $(>60 \%)$ of trace elements and alkaline-earth metals $(\mathrm{Ca}, \mathrm{Mg}, \mathrm{Sr}$, and $\mathrm{Ba})$ are present as colloids in the Ob River water in its middle course [47].

\subsection{MP Abundance in the Surface Water}

MPs were detected at all sampling sites. The average MP count in the surface water (items per $\mathrm{m}^{3}$ ) was 44.2 for the Tom River and 51.2 for the Ob River (Table 4). There were no statistically significant differences in MP average counts between the two rivers. The average MP mass was slightly higher in the Ob River compared to the Tom River (87.5 $\mu \mathrm{g}$ per $\mathrm{m}^{3}$ vs. $79.4 \mu \mathrm{g}$ per $\left.\mathrm{m}^{3}\right)$. However, the difference was still insignificant $(p>0.05)$. The total mass of the MPs detected in this study was found to be lower than MP pollution in some of the reported international surface waters. For instance, plastic pollution in Swiss surface waters was estimated at the level of $1.4 \mathrm{mg} \mathrm{m}^{-3}$ [49]. The abundance of MPs in the water of the Antuã River (Portugal) ranged from 5 to $51.7 \mathrm{mg} \mathrm{m}^{-3}$ [50]. MP concentrations measured in four estuarine tributaries within the Chesapeake Bay, U.S.A. ranged over three orders of magnitude, from $<1.0 \mathrm{~g} \mathrm{~km}^{-2}$ to $563 \mathrm{~g} \mathrm{~km}^{-2}$ [51]. 
Table 3. Elemental composition of the water.

\begin{tabular}{|c|c|c|c|c|c|c|c|c|c|}
\hline Sampling Sites & $1-\mathrm{T}$ & $2-\mathrm{T}$ & $3-\mathrm{T}$ & $4-\mathrm{T}$ & $1-O$ & $2-\mathrm{O}$ & $3-\mathrm{O}$ & $4-\mathrm{O}$ & $5-\mathrm{O}$ \\
\hline \multicolumn{10}{|c|}{$\begin{array}{l}\text { Elements content, } \mathrm{mg} \\
\qquad \mathrm{L}^{-1}\end{array}$} \\
\hline $\mathrm{Na}$ & 6.94 & 5.63 & 8.06 & 6.56 & 10.1 & 6.22 & 7.25 & 4.85 & 4.39 \\
\hline Mg & 4.61 & 2.51 & 3.66 & 3.37 & 5.20 & 4.91 & 4.84 & 3.38 & 3.59 \\
\hline K & 0.36 & 0.32 & 0.35 & 0.49 & 0.90 & 0.96 & 1.05 & 0.72 & 1.08 \\
\hline $\mathrm{Ca}$ & 29.5 & 14.2 & 20.8 & 19.2 & 30.8 & 30.2 & 32.4 & 23.3 & 24.0 \\
\hline $\mathrm{Si}$ & 1.67 & 1.31 & 1.50 & 2.41 & 2.03 & 1.73 & 2.08 & 1.92 & 3.05 \\
\hline $\mathrm{Fe}$ & 0.13 & 0.06 & 0.08 & 0.08 & 0.12 & 0.12 & 0.12 & 0.20 & 0.33 \\
\hline \multicolumn{10}{|c|}{$\begin{array}{l}\text { Elements content, } \mu \mathrm{g} \\
\qquad \mathrm{L}^{-1}\end{array}$} \\
\hline $\mathbf{L i}$ & 3.00 & 3.00 & 3.70 & 4.00 & 6.30 & 2.10 & 2.9 & 2.2 & 2.9 \\
\hline Al & 7.00 & 16.0 & 15.0 & 8.80 & 3.00 & 4.20 & 4.0 & 4.5 & 12.0 \\
\hline $\mathbf{P}$ & $<10.0$ & $<10.0$ & $<10.0$ & 20.3 & $<10.0$ & 11.0 & $<10.0$ & 15.0 & 31.0 \\
\hline $\mathbf{V}$ & $<1.00$ & 1.10 & $<1.00$ & $<1.00$ & 1.70 & 2.00 & 2.30 & 1.20 & $<1.00$ \\
\hline Mn & 66.0 & 9.50 & 1.90 & 5.00 & 6.50 & 6.70 & 12.0 & 1.40 & 50.0 \\
\hline Co & 0.14 & $<0.10$ & $<0.10$ & $<0.10$ & $<0.10$ & $<0.10$ & $<0.10$ & $<0.10$ & 0.22 \\
\hline $\mathrm{Ni}$ & 1.40 & $<1.00$ & 1.01 & 1.20 & 1.50 & 1.40 & 1.60 & 1.50 & 2.60 \\
\hline $\mathrm{Cu}$ & $<1.00$ & $<1.00$ & $<1.00$ & $<1.00$ & 1.30 & 0.14 & 1.60 & 1.10 & 1.40 \\
\hline $\mathrm{Zn}$ & $<1.00$ & 1.10 & $<1.00$ & 3.20 & $<1.00$ & $<1.00$ & $<1.00$ & $<1.00$ & $<1.00$ \\
\hline As & 1.03 & 1.20 & $<1.00$ & $<1.00$ & 1.50 & 1.80 & 1.90 & 1.10 & 1.10 \\
\hline $\mathbf{R b}$ & 0.30 & 0.22 & 0.25 & 0.31 & 0.40 & 0.40 & 0.46 & 0.36 & 1.1 \\
\hline $\mathrm{Sr}$ & 140 & 76.0 & 120 & 120 & 140 & 150 & 150 & 120 & 130 \\
\hline $\mathbf{Y}$ & $<0.10$ & $<0.10$ & $<0.10$ & $<0.10$ & $<0.10$ & $<0.10$ & $<0.10$ & $<0.10$ & 0.35 \\
\hline Mo & 0.55 & 0.88 & 0.67 & 0.68 & 0.80 & 0.80 & 0.78 & 0.54 & 0.39 \\
\hline $\mathrm{Sb}$ & $<0.10$ & $<0.10$ & $<0.10$ & $<0.10$ & 0.11 & 0.12 & 0.12 & $<0.10$ & $<0.10$ \\
\hline $\mathrm{Ba}$ & 28.0 & 20.0 & 22.0 & 23.0 & 23.0 & 18.0 & 21.0 & 18.0 & 27.0 \\
\hline La & $<0.10$ & $<0.10$ & $<0.10$ & $<0.10$ & $<0.10$ & $<0.10$ & $<0.10$ & $<0.10$ & 0.27 \\
\hline $\mathrm{Ce}$ & $<0.10$ & $<0.10$ & $<0.10$ & $<0.10$ & $<0.10$ & $<0.10$ & $<0.10$ & $<0.10$ & 0.35 \\
\hline $\mathrm{Nd}$ & $<0.10$ & $<0.10$ & $<0.10$ & $<0.10$ & $<0.10$ & $<0.10$ & $<0.10$ & $<0.10$ & 0.32 \\
\hline $\mathbf{U}$ & 0.51 & 0.26 & 0.55 & 0.25 & 0.86 & 0.68 & 0.80 & 0.46 & 0.25 \\
\hline
\end{tabular}

Table 4. Abundance ${ }^{1}$ of MPs in the surface water.

\begin{tabular}{|c|c|c|c|c|c|c|c|c|c|}
\hline \multirow{2}{*}{ Sampling Sites } & \multicolumn{4}{|c|}{ The River Tom } & \multicolumn{5}{|c|}{ The River $\mathrm{Ob}$} \\
\hline & $1-\mathrm{T}$ & $2-\mathrm{T}$ & $3-T$ & $4-\mathrm{T}$ & $1-\mathrm{O}$ & $2-\mathrm{O}$ & $3-\mathrm{O}$ & $4-\mathrm{O}$ & $5-\mathrm{O}$ \\
\hline $\begin{array}{l}\text { Total mass, } \\
\mu \mathrm{g} \mathrm{m}^{-3}\end{array}$ & $199 \pm 67.8$ & $47.7 \pm 32.6$ & $22.9 \pm 3.35$ & $47.9 \pm 28.1$ & $89.3 \pm 6.22$ & $56.0 \pm 5.65$ & $89.1 \pm 29.5$ & $96.2 \pm 9.26$ & $107 \pm 12.6$ \\
\hline $\begin{array}{l}\text { Average, } \\
\mu \mathrm{g} \mathrm{m}^{-3}\end{array}$ & \multicolumn{4}{|c|}{$79.4 \pm 80.6$} & \multicolumn{5}{|c|}{$87.5 \pm 19.1$} \\
\hline Total count, items $\mathrm{m}^{-3}$ & $57.2 \pm 10.3$ & $37.7 \pm 13.9$ & $52.6 \pm 5.54$ & $29.2 \pm 14.5$ & $114 \pm 6.76$ & $35.4 \pm 6.31$ & $26.5 \pm 11.8$ & $29.3 \pm 3.61$ & $50.4 \pm 6.04$ \\
\hline $\begin{array}{c}\text { Average, } \\
{\text { items } \mathrm{m}^{-3}}^{\text {ite }}\end{array}$ & \multicolumn{4}{|c|}{$44.2 \pm 13.0$} & \multicolumn{5}{|c|}{$51.2 \pm 36.5$} \\
\hline
\end{tabular}

${ }^{1}$ arithmetic mean \pm standard deviation.

As summarized by [52], global MP item concentrations in freshwater environments vary from 0.03 to 153 items per $\mathrm{m}^{3}$. In addition, a study by [53] demonstrated that the concentration of plastic debris in the Great Lakes tributaries were a maximum concentration of 32 and a mean of 4.2 items per $\mathrm{m}^{3}$ when using $0.33 \mathrm{~mm}$ mesh net. On average $5.6 \mathrm{MP}$ items per $\mathrm{m}^{3}$ were counted in the Rhine River between Basel and Rotterdam using $0.30 \mathrm{~mm}$ mesh net [54]; $0.32 \pm 4.66$ items per $\mathrm{m}^{3}$ were detected in the water of the Danube River in a two-year survey using a $0.50 \mathrm{~mm}$ mesh driftnet [55]; and the abundance of MPs in the surface water of the Marne River in France when sampled with $0.08 \mathrm{~mm}$ mesh net ranged from 5.70 to 398 items per $\mathrm{m}^{3}$, with a mean of 101 items per $\mathrm{m}^{3}$ [56]. The highest abundance of MPs between 1 and $4.75 \mathrm{~mm}$ in size reached 153 items per $\mathrm{m}^{3}$ in water samples from the San Gabriel River system where 0.33 mesh net was used for sampling [26]. This demonstrates that the levels of MPs in the sampled rivers of western 
Siberia in this study are comparable by total counts with the reported levels around the world. However, quantitative estimates are highly dependent on the used sampling method and it is suggested that many studies could be underestimating the number of MPs present in river systems [25].

Concentrations of total MP in the surface water samples in the Ob River ranged from 26.5 to 114 items per $\mathrm{m}^{3}$ (Table 4 ). The highest MP content by total counts $(114 \pm 6.76$ items per $\mathrm{m}^{3}$ ) was detected in the surface water of the Ob River downstream of Novosibirsk at site 1-O. Current population in the urban area of Novosibirsk is $1,667,734$ [57]. Population density and urbanization affect the abundance of MPs [53,58]. Previous studies demonstrate that MPs are accumulated in proximity to cities with relatively high population and plastic use, usually associated with high wastewater inputs [25,59-62]. Wastewater and sewage treatment plants are the largest contributors of MP discharge into waterways $[58,63,64]$. Although significant amounts of MP particles are removed from treated wastewater, approximately $5 \%$ of MP are not filtered and can enter natural water systems $[65,66]$.

Population density is not the only factor determining MP accumulation. Kemerovo and Tomsk are comparable in population density (566,534 and 597,607 people in the urban area, correspondingly), yet in water sampled downstream of Kemerovo (1-T), a significantly higher number and mass of MP particles were found compared to sample 4-T collected near Tomsk (Table 4). Kemerovo is the largest coal and metallurgical center in Russia, and one of the main industrial regions of the country [67], and both activities are likely the major sources of MP discharge into the waterway. Fishing can also be a source of primary plastic debris [5]. The total mass of the MP in the samples from the site downstream of Novosibirsk consisted $89.3 \pm 6.22 \mu \mathrm{g}$ per $\mathrm{m}^{3}$. The number of particles at the $1-\mathrm{O}$ site was the highest among all sampling sites, but the mass is not. The explanation for this is in the size and shape of the particles. The minimum number of spheres was found in this sample. Interestingly the total mass of the MPs sampled at the 1-O site was lower than those in the northern sites 4-O and 5-O which are fishing centers and sources of fishing equipment pollution (96.2 \pm 9.26 and $107 \pm 12.6 \mu \mathrm{g}$ per $\mathrm{m}^{3}$, respectively). It has been reported that sport fishing is the main source for MPs detected in the Dalålven River in Sweden, a relatively clean river with a small population $(250,000)$ living in its basin [30].

Analysis of the types of MP found at each site may provide some evidence for the sources of the plastics in the studied rivers, whereas the composition of MPs in terms of particle shapes would give indication on their origin [54].

\subsection{Morphological Characteristics of the Detected MP}

The vast majority of detected particles (93.5\%) were less than $1 \mathrm{~mm}$ by their largest dimension (Table 4, Figure 2) and, implicitly fell under the definition of "microplastic" as recommended by some authors [2,3]. Only $6.50 \%$ of the particles detected in the surface water in the current study were in the $1.00-5.00 \mathrm{~mm}$ size range, while $5.83 \%$ were under $2.00 \mathrm{~mm}$. The largest fraction of the MP particles under $1.00 \mathrm{~mm}$ were in the $0.30-1.00 \mathrm{~mm}$ size range $(45.5 \%)$, while $13.9 \%$ and $9.3 \%$ of the particles ranged from $0.15-0.30$ and $<0.15 \mathrm{~mm}$, respectively (Table 4, Figure 2).

All MP particles extracted from the surface water of the Ob River and its tributary the Tom River were classified by shape as: (1) microfragments, (2) microfilms, (3) microspheres, and (4) microfibers (Figure S2). While the nomenclature used for the shape taxonomies is not standardized, these terms are the most used in the literature for MP morphology description along with "foams" [1]. Foams were not detected in large amounts in the current study, hence they were combined together with other irregular-shaped particles and flakes, and designated as "microfragments", in accordance with Hartmann et al. [3]. The elongated shape-like fibers and lines were combined under the category "microfibers". 


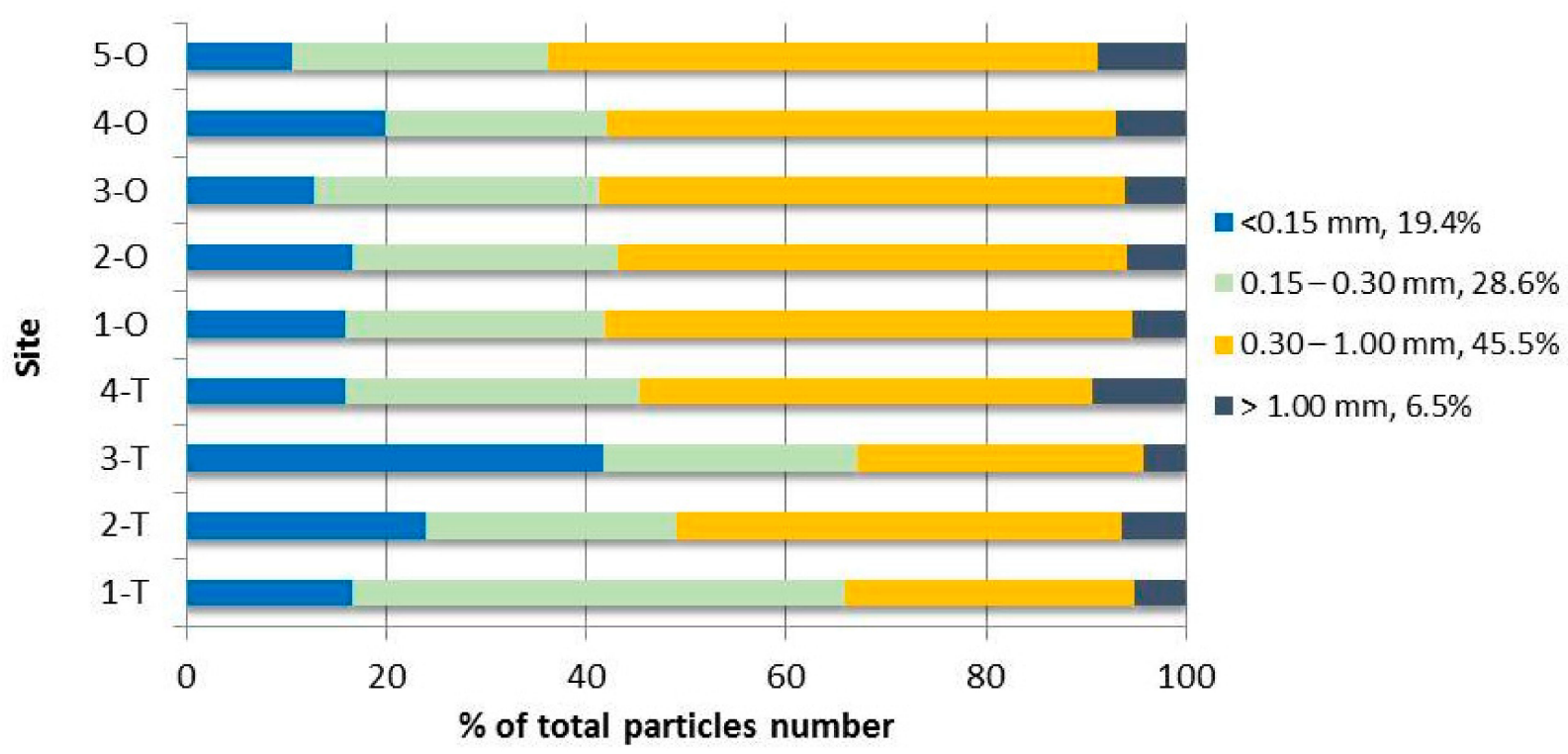

Figure 2. Percent composition of MP sizes (size from $<0.15$ to $5.00 \mathrm{~mm}$ ) for each sampling site. The average percentages across all sampling sites are shown in the legend.

Microfragments were most abundant in the studied samples (21.3 items per $\mathrm{m}^{3}$ or $47.4 \%$ in average), while the content of other forms of MP varied from site to site (Table 5, Figure 3). Microfibers, microfilms, and microspheres made up $22.1 \%, 20.8 \%$, and $9.74 \%$, respectively, of the average counts of all MPs detected (Figure 3). In some instances, statistically significant differences in the abundance of different MP shapes between the sample sites were noted (Table 6). This difference is most noticeable in relation to fragments and spheres. Surface water sampled at sample site 1-O (Ob River downstream of Novosibirsk) was distinguished by high content $(56.1 \%)$ of microfibers (Figure 3, Table 5). The likely source of these fibers is wastewater releases, and given that Novosibirsk has the largest population in the region, inputs of these discharges is greater than the other sampled areas.

MP types like fibers and spheres (namely pellets) are often associated with synthetic textiles and personal care products [64]. Therefore, both microfibers (mostly synthetic fabrics) and microbeads (abrasives in personal care products and other) are abundant in wastewater treatment plant effluent, which can serve as a point source of MP pollution in rivers [66,68-71]. Habib et al. [68] observed a decrease in concentration of synthetic fibers in rivers the further the distance from wastewater treatment plants, demonstrating their contribution to MP pollution. According to a study by Siegfried et al. [72], most MPs discharged into seas by rivers were synthetic polymers from wastewater treatment plants $(42 \%)$ and plastic-based textiles from laundries $(29 \%)$, while smaller sources of synthetic polymers and MP fibers came from household dust (19\%) and personal care products microbeads $(10 \%)$. Recent evidence suggests that atmospheric transport is also an important route and source of microfibers entering soils and aquatic ecosystems [17,73]. Baldwin et al. [53] demonstrated the contribution of industrial sources to MP concentration of pellets/beads in the Great Lakes; however, no correlation between concentration of the spherical MP and wastewater effluent was demonstrated. Microbeads in natural waters can also be associated with industrial abrasive blasting media $[5,74,75]$. Raw plastic pellets are often abundant close to plastic manufacturing plants $[26,76]$ because of their usage in plastics processing. 
Table 5. Abundance ${ }^{1}$ of MP sizes and shapes in the surface water.

\begin{tabular}{|c|c|c|c|c|c|c|c|c|c|c|}
\hline Scheme 1. & $1-\mathrm{T}$ & $2-T$ & $3-\mathrm{T}$ & $4-\mathrm{T}$ & $1-0$ & $2-\mathrm{O}$ & $3-\mathrm{O}$ & $4-\mathrm{O}$ & $5-\mathrm{O}$ & Av. \\
\hline \multicolumn{11}{|l|}{ Sizes, items $\mathrm{m}^{-3}$} \\
\hline$<0.15 \mathrm{~mm}$ & $9.52 \pm 3.09$ & $9.07 \pm 3.29$ & $21.9 \pm 3.46$ & $4.67 \pm 3.70$ & $18.3 \pm 5.63$ & $5.90 \pm 2.61$ & $3.37 \pm 0.44$ & $5.84 \pm 1.19$ & $5.33 \pm 1.76$ & 9.328 \\
\hline $0.15-0.30 \mathrm{~mm}$ & $28.2 \pm 6.74$ & $9.41 \pm 3.96$ & $13.4 \pm 2.37$ & $8.60 \pm 1.21$ & $29.6 \pm 14.9$ & $9.38 \pm 4.72$ & $7.61 \pm 2.20$ & $6.48 \pm 5.43$ & $12.9 \pm 7.27$ & 13.94 \\
\hline $0.30-1.00 \mathrm{~mm}$ & $16.6 \pm 12.5$ & $16.8 \pm 17.2$ & $15.1 \pm 6.15$ & $13.2 \pm 13.4$ & $60.2 \pm 7.26$ & $18.1 \pm 4.09$ & $13.9 \pm 10.0$ & $14.9 \pm 2.24$ & $27.7 \pm 7.38$ & 21.83 \\
\hline $1.00-2.00 \mathrm{~mm}$ & $2.46 \pm 2.11$ & $2.14 \pm 1.86$ & $2.06 \pm 1.70$ & $2.29 \pm 1.81$ & $5.99 \pm 1.41$ & $1.87 \pm 1.63$ & $1.38 \pm 0.75$ & $2.07 \pm 0.59$ & $3.99 \pm 2.85$ & 2.696 \\
\hline $2.00-3.00 \mathrm{~mm}$ & $0.37 \pm 0.21$ & $0.19 \pm 0.02$ & $0.13 \pm 0.08$ & $0.27 \pm 0.25$ & $0.19 \pm 0.06$ & $0.22 \pm 016$ & $0.20 \pm 0.20$ & nd & $0.48 \pm 0.35$ & 0.227 \\
\hline $3.00-4.00 \mathrm{~mm}$ & $0.04 \pm 0.04$ & $0.08 \pm 0.07$ & nd & $0.18 \pm 0.20$ & $0.04 \pm 0.02$ & nd & $0.05 \pm 0.09$ & nd & nd & 0.043 \\
\hline $4.00-5.00 \mathrm{~mm}$ & $0.04 \pm 0.04$ & nd & nd & nd & nd & nd & nd & nd & nd & 0.004 \\
\hline \multicolumn{11}{|c|}{ Shapes, items $\mathrm{m}^{-3}$} \\
\hline Spheres & $32.5 \pm 10.8$ & $3.41 \pm 2.01$ & $0.92 \pm 0.55$ & $2.47 \pm 0.89$ & $0.95 \pm 0.54$ & $0.77 \pm 1.09$ & $0.51 \pm 0.47$ & $1.30 \pm 0.62$ & $1.14 \pm 1.32$ & 4.886 \\
\hline Films & $4.37 \pm 1.21$ & $7.69 \pm 3.03$ & $7.75 \pm 3.26$ & $6.95 \pm 1.99$ & $13.5 \pm 4.53$ & $11.3 \pm 4.24$ & $8.68 \pm 4.91$ & $5.19 \pm 1.69$ & $13.4 \pm 13.8$ & 8.759 \\
\hline Fibers/Lines & $4.18 \pm 3.45$ & $6.12 \pm 1.94$ & $7.40 \pm 3.09$ & $5.86 \pm 4.36$ & $64.2 \pm 4.94$ & $7.26 \pm 7.19$ & $4.70 \pm 2.94$ & $6.61 \pm 5.28$ & $12.2 \pm 6.78$ & 13.16 \\
\hline Fragments & $16.2 \pm 2.58$ & $20.5 \pm 11.0$ & $36.5 \pm 5.84$ & $13.9 \pm 11.0$ & $35.7 \pm 7.33$ & $16.1 \pm 4.52$ & $12.6 \pm 9.48$ & $16.2 \pm 1.52$ & $23.7 \pm 12.0$ & 21.27 \\
\hline
\end{tabular}

${ }^{1}$ arithmetic mean \pm standard deviation, "nd" - not detected. 


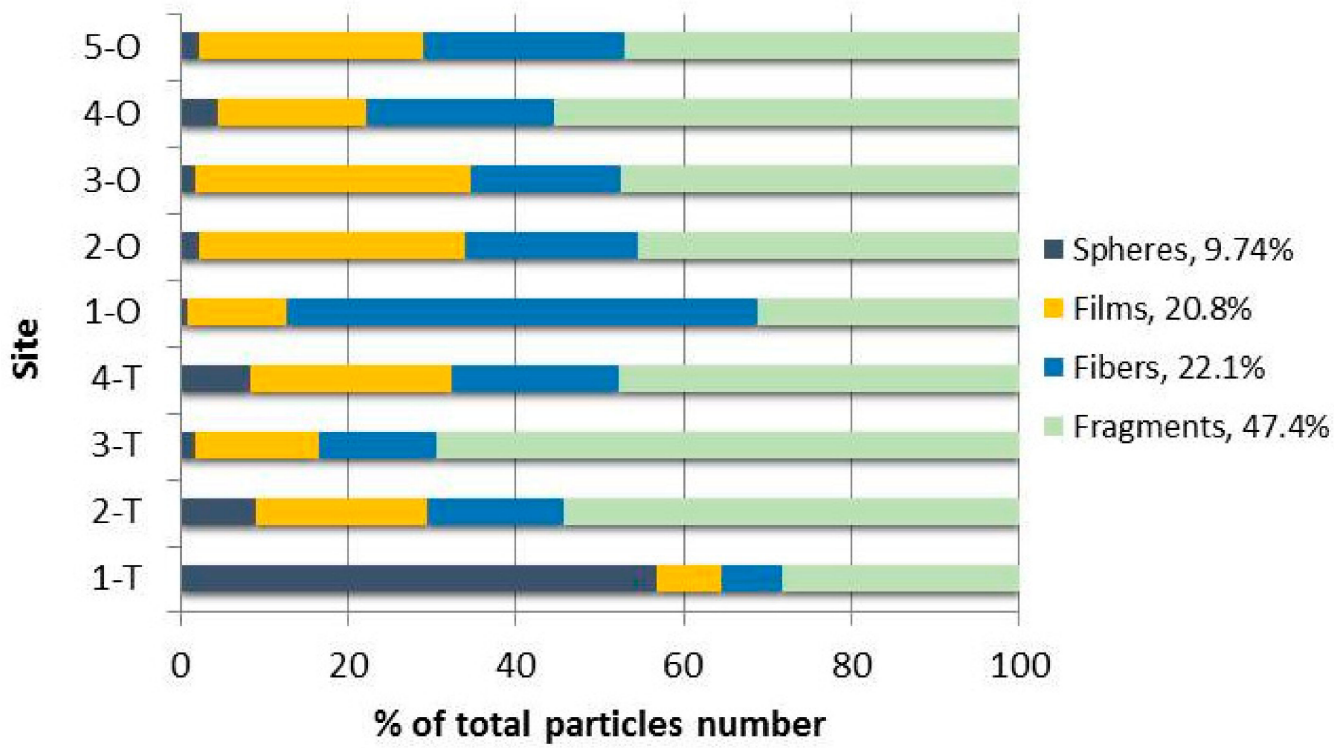

Figure 3. Percent composition of MP shapes (spheres, fibers and lines, films, fragments) for each sampling site. The average percentages across all sampling sites are shown in the legend.

Table 6. Differences in MP shapes between sites.

\begin{tabular}{|c|c|c|c|c|c|c|c|c|c|c|c|c|c|c|c|c|c|c|c|}
\hline Spheres & $1-\mathrm{T}$ & $2-\mathrm{T}$ & 3-T & $4-\mathrm{T}$ & $1-O$ & $2-0$ & 3-O & 4-O & $5-\mathrm{O}$ & Films & 1-T & 2-T & $3-\mathrm{T}$ & 4-T & $1-O$ & $2-\mathrm{O}$ & $3-0$ & $4-0$ & $5-\mathrm{O}$ \\
\hline $1-\mathrm{T}$ & & & & & & & & & & $1-\mathrm{T}$ & & & & & & & & & \\
\hline $2-\mathrm{T}$ & + & & & & & & & & & $2-\mathrm{T}$ & - & & & & & & & & \\
\hline 3-T & + & + & & & & & & & & 3-T & - & - & & & & & & & \\
\hline $4-\mathrm{T}$ & + & - & - & & & & & & & 4-T & - & - & - & & & & & & \\
\hline $1-\mathrm{O}$ & + & + & - & - & & & & & & $1-\mathrm{O}$ & + & - & - & + & & & & & \\
\hline $2-\mathrm{O}$ & + & + & - & - & - & & & & & $2-\mathrm{O}$ & + & - & - & - & - & & & & \\
\hline $3-\mathrm{O}$ & + & + & - & + & - & - & & & & $3-\mathrm{O}$ & - & - & - & - & - & - & & & \\
\hline $4-\mathrm{O}$ & + & + & - & - & - & - & + & & & $4-\mathrm{O}$ & - & - & - & - & + & + & - & & \\
\hline $5-\mathrm{O}$ & + & - & - & - & - & - & - & - & & $5-\mathrm{O}$ & - & - & - & - & - & - & - & - & \\
\hline Fibers & $1-\mathrm{T}$ & $2-\mathrm{T}$ & 3-T & 4-T & $1-0$ & $2-\mathrm{O}$ & 3-O & 4-O & 5-O & Fragments & 1-T & 2-T & 3-T & $4-\mathrm{T}$ & $1-0$ & $2-\mathrm{O}$ & $3-\mathrm{O}$ & 4-O & 5-O \\
\hline $1-\mathrm{T}$ & & & & & & & & & & 1-T & & & & & & & & & \\
\hline $2-\mathrm{T}$ & - & & & & & & & & & $2-\mathrm{T}$ & - & & & & & & & & \\
\hline 3-T & - & - & & & & & & & & 3-T & + & - & & & & & & & \\
\hline $4-\mathrm{T}$ & - & - & - & & & & & & & 4-T & - & - & + & & & & & & \\
\hline $1-\mathrm{O}$ & + & + & + & + & & & & & & $1-\mathrm{O}$ & + & - & - & + & & & & & \\
\hline $2-\mathrm{O}$ & - & - & - & - & + & & & & & $2-\mathrm{O}$ & - & - & + & - & + & & & & \\
\hline $3-\mathrm{O}$ & - & - & - & - & + & - & & & & $3-\mathrm{O}$ & - & - & + & - & + & - & & & \\
\hline $4-\mathrm{O}$ & - & - & - & - & + & - & - & & & $4-\mathrm{O}$ & - & - & + & - & + & - & - & & \\
\hline $5-\mathrm{O}$ & - & - & - & - & + & - & - & - & & $5-\mathrm{O}$ & - & - & - & - & - & - & - & - & \\
\hline
\end{tabular}

There was no significant difference in the abundance of fragments, films, and fibers between the two rivers. However, there were significant differences in the abundance of spheres in the Tom River. The obtained empirical value $U=31$ was in the zone of significance at $p<0.01$. The highest abundance $(56.8 \%)$ of spherical microparticles was noted at the sampling site 1-T (downstream of Kemerovo) in the Tom River. The spherical MPs are described as "microbeads" and "pellets" with the suggested threshold between microbeads and micropellets as spherical plastic particles $1 \mathrm{~mm}$ in size (microbeads $<1 \mathrm{~mm}$ and micropellets $>1 \mathrm{~mm}$ ) [2]. All the microspheres detected in the current samples were under $1 \mathrm{~mm}$ in diameter (Figure S2) and belonged to microbeads. The significantly higher values of microspheres found at the 1-T site $(58.8 \%)$ were likely related to industrial source, particularly from plastic manufacturing plants which are prolific in this area. Similarly, longitudinal trends in detected MP types that relate to locally prevailing contamination sources were previously observed along rivers [25]. 


\section{Conclusions}

This study has, for the first time, determined the presence and abundance of MPs in surface water of the Ob River system in western Siberia. Data taken from the Ob and Tom rivers indicate that MPs are relatively ubiquitous in the water, with particles occurring in all sites sampled from the $\mathrm{Ob}$ River in its upper and middle course and its large tributary, the Tom River. The average number of particles for the two rivers ranged from 44.2 to 51.2 items per $\mathrm{m}^{3}$ or from 79.4 to $87.5 \mu \mathrm{g}$ per $\mathrm{m}^{3}$ in the Tom River and the Ob River, respectively, demonstrating that MPs are an issue in these remote areas. In terms of frequency of particle sizes occurrence, $0.30-1.00 \mathrm{~mm}$ particles were the most abundant, followed by $0.15-0.30 \mathrm{~mm}$ particles and particles $<0.15 \mathrm{~mm}$. Microfragments were the most abundant overall by sampling sites. However, no significant difference in abundance of fragments, films, and fibers between the two rivers was detected. In contrast, the abundance of spheres referred to as microbeads was significantly higher in one sample site on the Tom River.

The study demonstrates potential correlation between the distribution of MPs, the size of local populations, and activities undertaken, including industrial activities near the sampling areas. Nevertheless, the location of the sources of MPs requires long-term and regular monitoring to establish a connection between population and activities, including possible sources of MPs entering the Ob River system. This would enable further, comprehensive, quantitative estimates of MPs discharging into the Arctic Ocean.

Supplementary Materials: The following are available online at https://www.mdpi.com/2071 $-1050 / 13 / 1 / 80 /$ s1, Figure S1. Sampling of surface water on the Ob River (Site 1-O). Figure S2. Microphotographs of recovered material.

Author Contributions: D.S.V., A.A.T. and Y.A.F. conceived the study and contributed to the design and implementation of the research. D.S.V., A.A.T., Y.A.F., E.D.V. and D.V.A. performed the sampling and fieldwork. Y.A.F., E.D.V., D.V.A. and T.S.H. contributed to the analysis of the results. Y.A.F. and A.A.T. wrote the manuscript in consultation with T.S.H. S.P.W. and V.S. reviewed the draft manuscript and suggested changes to the final submitted version. All authors have read and agreed to the published version of the manuscript.

Funding: This research was funded by the Tomsk State University of competitiveness improvement program (research grant No. 8.2.08.2020).

Institutional Review Board Statement: Not applicable.

Informed Consent Statement: Not applicable.

Conflicts of Interest: There are no conflicts or competing interests to declare.

\section{References}

1. Frias, J.P.G.L.; Nash, R. Microplastics: Finding a consensus on the definition. Mar. Pollut. Bull. 2019, 138, 145-147. [CrossRef] [PubMed]

2. Cowger, W.; Gray, A.B.; Eriksen, M.; Moore, C.; Thiel, M. Evaluating wastewater effluent as a source of microplastics in environmental samples. In Microplastics in Water and Wastewater; Karapanagioti, H.K., Kalavrouziotis, I.K., Eds.; IWA Publishing: London, UK, 2019; pp. 109-131. [CrossRef]

3. Hartmann, N.B.; Hüffer, T.; Thompson, R.C.; Hassellöv, M.; Verschoor, A.; Daugaard, A.E.; Rist, S.; Karlsson, T.; Brennholt, N.; Cole, M.; et al. Are we speaking the same language? Recommendations for a definition and categorization framework for plastic debris. Environ. Sci. Technol. 2019, 53, 1039-1047. [CrossRef] [PubMed]

4. Barnes, D.K.A.; Galgani, F.; Thompson, R.C.; Barlaz, M. Accumulation and fragmentation of plastic debris in global environments. Phil. Trans. R. Soc. 2009, 364, 1985-1998. [CrossRef] [PubMed]

5. Boucher, J.; Friot, D. Primary Microplastics in the Oceans: A Global Evaluation of Sources; IUCN: Gland, Switzerland, 2017; 43p. [CrossRef]

6. Chae, Y.; An, Y.J. Effects of micro- and nanoplastics on aquatic ecosystems: Current research trends and perspectives. Mar. Pollut. Bull. 2017, 124, 624-632. [CrossRef]

7. Sharma, S.; Chatterjee, S. Microplastic pollution, a threat to marine ecosystem and human health: A short review. Environ. Sci. Pollut. Res. 2017, 24, 21530-21547. [CrossRef]

8. Campanale, C.; Massarelli, C.; Savino, I.; Locaputo, V.; Uricchio, V.F. A detailed review study on potential effects of microplastics and additives of concern on human health. Int. J. Environ. Res. Public Health 2020, 17, 1212. [CrossRef] 
9. Wang, W.; Gao, H.; Jin, S.; Li, R.; Na, G. The ecotoxicological effects of microplastics on aquatic food web, from primary producer to human: A review. Ecotoxicol. Environ. Saf. 2019, 173, 110-117. [CrossRef]

10. Rubio, L.; Marcos, R.; Hernández, A. Potential adverse health effects of ingested micro- and nanoplastics on humans. Lessons learned from in vivo and in vitro mammalian models. J. Toxicol. Environ. Health B Crit. Rev. 2020, 23, 51-68. [CrossRef]

11. Yong, C.Q.Y.; Valiyaveetill, S.; Tang, B.L. Toxicity of microplastics and nanoplastics in mammalian systems. Int. J. Environ. Res. Public Health 2020, 17, 1509. [CrossRef]

12. Eerkes-Medrano, D.; Thompson, R.C.; Aldridge, D.C. Microplastics in freshwater systems: A review of the emerging threats, identification of knowledge gaps and prioritisation of research needs. Water Res. 2015, 75, 63-82. [CrossRef]

13. Wagner, M.; Scherer, C.; Alvarez-Muñoz, D.; Brennholt, N.; Bourrain, X.; Buchinger, S.; Fries, E.; Grosbois, C.; Klasmeier, J.; Marti, T.; et al. Microplastics in freshwater ecosystems: What we know and what we need to know. Environ. Sci. Eur. 2014, 26, 12. [CrossRef] [PubMed]

14. Lambert, S. Microplastics are contaminants of emerging concern in freshwater environments: An overview. In Freshwater microplastics. Emerging Environmental Contaminants; Wagner, M., Lambert, S., Eds.; Springer: Basel, Switzerland, 2018; pp. 1-23. [CrossRef]

15. Kim, H.; Lee, J.-Y. Emerging concerns about microplastic pollution on groundwater in South Korea. Sustainability 2020, $12,5275$. [CrossRef]

16. Scheurer, M.; Bigalke, M. Microplastics in Swiss floodplain soils. Environ. Sci. Technol. 2018, 52, 3591-3598. [CrossRef] [PubMed]

17. Brahney, J.; Hallerud, M.; Heim, E.; Hahnenberger, M.; Sukumaran, S. Plastic rain in protected areas of the United States. Science 2020, 368, 1257-1260. [CrossRef] [PubMed]

18. de Souza Machado, A.A.; Kloas, W.; Zarfl, C.; Hempel, S.; Rillig, M.C. Microplastics as an emerging threat to terrestrial ecosystems. Glob. Chang. Biol. 2018, 24, 1405-1416. [CrossRef] [PubMed]

19. Bergmann, M.; Mützel, S.; Primpke, S.; Tekman, M.B.; Trachsel, J.; Gerdts, G. White and wonderful? Microplastics prevail in snow from the Alps to the Arctic. Sci. Adv. 2019, 5, eaax1157. [CrossRef] [PubMed]

20. Allen, S.; Allen, D.; Phoenix, V.R.; Le Roux, G.; Durántez Jiménez, P.; Simonneau, A.; Binet, S.; Galop, D. Atmospheric transport and deposition of microplastics in a remote mountain catchment. Nat. Geosci. 2019, 12, 339-344. [CrossRef]

21. Wright, S.L.; Ulke, J.; Font, A.; Chan, K.L.A.; Kelly, F.J. Atmospheric microplastic deposition in an urban environment and an evaluation of transport. Environ. Int. 2020, 136, 105411. [CrossRef]

22. Rochman, C.M.; Hoellein, T. The global odyssey of plastic pollution. Thinking big about small particles reveals new features of the microplastic cycle. Science 2020, 368, 1184-1185. [CrossRef]

23. Wichmann, D.; Delandmeter, P.; van Sebille, E. Influence of near-surface currents on the global dispersal of marine microplastic. J. Geophys. Res. Ocean. 2019, 124, 6086-6096. [CrossRef]

24. Horton, A.A.; Walton, A.; Spurgeon, D.J.; Lahive, E.; Svendsen, C. Microplastics in freshwater and terrestrial environments: Evaluating the current understanding to identify the knowledge gaps and future research priorities. Sci. Total Environ. 2017, 586, 127-141. [CrossRef] [PubMed]

25. Skalska, K.; Ockelford, A.; Ebdon, J.E.; Cundy, A.B. Riverine microplastics: Behaviour, spatio-temporal variability, and recommendations for standardised sampling and monitoring. J. Water Proc. Eng. 2020, 38, 101600. [CrossRef]

26. Moore, C.; Lattin, G.; Zellers, A. Quantity and type of plastic debris flowing from two urban rivers to coastal waters and beaches of Southern California. J. Integr. Coast. Zone Manag. 2011, 11, 65-73. [CrossRef]

27. Eriksen, M.; Mason, S.; Wilson, S.; Box, C.; Zellers, A.; Edwards, W.; Farley, H.; Amato, S. Microplastic pollution in the surface waters of the Laurentian Great Lakes. Mar. Pollut. Bull. 2013, 77, 177-182. [CrossRef] [PubMed]

28. Nizzetto, L.; Bussi, G.; Futter, M.; Butterfield, D.; Whitehead, P. A theoretical assessment of microplastic transport in river catchments and their retention by soils and river sediments. Environ. Sci. Process. Impacts 2016, 18, 1050-1059. [CrossRef] [PubMed]

29. Bellasi, A.; Binda, G.; Pozzi, A.; Galafassi, S.; Volta, P.; Bettinetti, R. Microplastic contamination in freshwater environments: A review, focusing on interactions with sediments and benthic organisms. Environments 2020, 7, 30. [CrossRef]

30. van der Wal, M.; Van Der Meulen, M.; Tweehuijsen, G.; Peterlin, M.; Palatinus, A.; Kovač Viršek, M.; Coscia, L.; Kržan, A. Identification and Assessment of Riverine Input of (Marine) Litter; European Commission: Bruxelles, Belgium, 2015; 186p.

31. McClelland, J.W.; Holmes, R.M.; Peterson, B.J.; Stieglitz, M. Increasing river discharge in the Eurasian Arctic: Consideration of dams, permafrost thaw, and fires as potential agents of change. J. Geophys. Res. 2004, 109, D18102. [CrossRef]

32. Lammers, R.B.; Shiklomanov, A.I.; Vörösmarty, C.J.; Fekete, B.M.; Peterson, B.J. Assessment of contemporary Arctic river runoff based on observational discharge records. J. Geophys. Res. 2001, 106, 3321-3334. [CrossRef]

33. Kirpotin, S.N. The great Ob River basin. Int. J. Environ. Stud. 2015, 72, 377-379. [CrossRef]

34. Ivanov, K.S.; Erokhin, Y.V.; Ponomarev, V.S.; Pogromskaya, O.E.; Berzin, S.V. Geological structure of the basement of western and eastern parts of the West-Siberian Plain. Int. J. Sci. Educ. 2016, 11, 6409-6432.

35. Ulmishek, G.F. Petroleum Geology and Resources of the West Siberian Basin, Russia; U.S. Geological Survey Bulletin 2201-G; U.S. Geological Survey: Reston, VA, USA, 2003; 49p.

36. The State Water Register. Available online: http:/ / textual.ru/gvr/ (accessed on 12 October 2020).

37. Campanale, C.; Savino, I.; Pojar, I.; Massarelli, C.; Uricchio, V.F. A Practical overview of methodologies for sampling and analysis of microplastics in riverine environments. Sustainability 2020, 12, 6755. [CrossRef] 
38. Andrady, A.L. The plastic in microplastics: A review. Mar. Pollut. Bull. 2017, 119, 12-22. [CrossRef] [PubMed]

39. Water Measurement Manual. A Water Resources Technical Publication, Dodge, R. (Ed.) U.S. Department of the Interior Bureau of Reclamation, Third Edition; U.S. Government Printing Office: Denver, CO, USA, 2001; 317p.

40. Fernández-Turiel, J.L.; Llorens, J.F.; López-Vera, F.; Gómez-Artola, C.; Morell, I.; Gimeno, D. Strategy for water analysis using ICP-MS. Fresenius J. Anal. Chem. 2000, 368, 601-606. [CrossRef] [PubMed]

41. Pokrovsky, O.S.; Shirokova, L.S. Diurnal variations of dissolved and colloidal organic carbon and trace metals in a boreal lake during summer bloom. Water Res. 2013, 47, 922-932. [CrossRef]

42. Masura, J.; Baker, J.; Foster, G.; Arthur, C. Laboratory Methods for the Analysis of Microplastics in the Marine Environment: Recommendations for Quantifying Synthetic Particles in Waters and Sediments; NOAA Technical Memorandum NOS-OR\&R-48; NOAA Marine Debris Division: Silver Spring, MD, USA, 2015; 39p.

43. McCormick, A.R.; Hoellein, T.J.; London, M.G.; Hittie, J.; Scott, J.W.; Kelly, J.J. Microplastic in surface waters of urban rivers: Concentration, sources, and associated bacterial assemblages. Ecosphere 2016, 7, e01556. [CrossRef]

44. Koelmans, A.A.; Nor, N.H.M.; Hermsen, E.; Kooi, M.; Mintenig, S.M.; De France, J. Microplastics in freshwaters and drinking water: Critical review and assessment of data quality. Water Res. 2019, 155, 410-422. [CrossRef]

45. Mann, H.B.; Whitney, D.R. On a test of whether one of two random variables is stochastically larger than the other. Ann. Math. Stat. 1947, 18, 50-60. [CrossRef]

46. Kruskal, W.H.; Wallis, W.A. Use of ranks in one-criterion variance analysis. J. Am. Stat. Assoc. 1952, 47, 583-621. [CrossRef]

47. Vorobyev, S.N.; Pokrovsky, O.S.; Kirpotin, S.N.; Kolesnichenko, L.G.; Shirokova, L.S.; Manasypov, R.M. Flood zone biogeochemistry of the Ob River middle course. J. Appl. Geochem. 2015, 63, 133e145. [CrossRef]

48. Søndergaard, M. Redox potential. Reference module in earth systems and environmental sciences. In Encyclopedia of Inland Waters; Likens, G.E., Ed.; Academic Press: Cambridge, MA, USA, 2008; Volume 3, pp. 852-859.

49. Faure, F.; Demars, A.C.; Wieser, A.O.; Kunz, M.; de Alencastro, L.F. Plastic pollution in Swiss surface waters: Nature and concentrations, interaction with pollutants. Environ. Chem. 2015, 12, 582-591. [CrossRef]

50. Rodrigues, M.O.; Abrantes, N.; Gonçalves, F.J.M.; Nogueira, H.; Marques, J.C.; Gonçalves, A.M.M. Spatial and temporal distribution of microplastics in water and sediments of a freshwater system (Antuã River, Portugal). Sci. Total Environ. 2018, 633, 1549-1559. [CrossRef] [PubMed]

51. Yonkos, L.T.; Friedel, E.A.; Perez-Reyes, A.C.; Ghosal, S.; Arthur, C.D. Microplastics in four estuarine rivers in the Chesapeake Bay, USA. Environ. Sci. Technol. 2014, 48, 14195-14202. [CrossRef] [PubMed]

52. Campanale, C.; Stock, F.; Massarelli, C.; Kochleus, C.; Bagnuolo, G.; Reifferscheid, G.; Uricchio, V.F. Microplastics and their possible sources: The example of Ofanto river in southeast Italy. Environ. Pollut. 2020, 258, 113284. [CrossRef] [PubMed]

53. Baldwin, A.K.; Corsi, S.R.; Mason, S.A. Plastic debris in 29 great lakes tributaries: Relations to watershed attributes and hydrology. Environ. Sci. Technol. 2016, 50, 10377-10385. [CrossRef] [PubMed]

54. Mani, T.; Hauk, A.; Walter, U. and Burkhardt-Holm, P. Microplastics profile along the Rhine River. Sci. Rep. 2015, 5, 17988. [CrossRef] [PubMed]

55. Lechner, A.; Keckeis, H.; Lumesberger-Loisl, F.; Zens, B.; Krusch, R.; Tritthart, M.; Glas, M.; Schludermann, E. The Danube so colourful: A potpourri of plastic litter outnumbers fish larvae in Europe's second largest river. Environ. Pollut. 2014, 188, 177-181. [CrossRef] [PubMed]

56. Dris, R.; Gasperi, J.; Tassin, B. Sources and fate of microplastics in urban areas: A focus on Paris Megacity. In Freshwater Microplastics: The Handbook of Environmental Chemistry; Wagner, M., Lambert, S., Eds.; Springer: Cham, Switzerland, 2018; Volume 58, pp. 69-83. [CrossRef]

57. Population Stat. World Statistical Data. Available online: https:/ / populationstat.com/ (accessed on 3 November 2020).

58. Wong, J.K.H.; Lee, K.K.; Tang, K.H.D.; Yap, P.-S. Microplastics in the freshwater and terrestrial environments: Prevalence, fates, impacts and sustainable solutions. Sci. Total Environ. 2020, 719, 137512. [CrossRef]

59. Kusui, T.; Noda, M. International survey on the distribution of stranded and buried litter on beaches along the Sea of Japan. Mar. Pollut. Bull. 2003, 47, 175-179. [CrossRef]

60. Browne, M.A.; Crump, P.; Niven, S.J.; Teuten, E.; Tonkin, A.; Galloway, T.; Thompson, R. Accumulation of microplastic on shorelines worldwide: Sources and sinks. Environ. Sci. Technol. 2011, 45, 9175-9179. [CrossRef]

61. Desforges, J.P.; Galbraith, M.; Dangerfield, N.; Ross, P.S. Widespread distribution of microplastics in subsurface seawater in the NE Pacific Ocean. Mar. Pollut. Bull. 2014, 79, 94-99. [CrossRef]

62. Jahan, S.; Strezov, V.; Weldekidan, H.; Kumar, R.; Kan, T.; Sarkodie, S.A.; He, J.; Dastjerdi, B.; Wilson, S.P. Interrelationship of microplastic pollution in sediments and oysters in a seaport environment of the eastern coast of Australia. Sci. Total Environ. 2019, 695, 133924. [CrossRef] [PubMed]

63. Talvitie, J.; Heinonen, M.; Pääkkönen, J.P.; Vahtera, E.; Mikola, A.; Setälä, O.; Vahala, R. Do wastewater treatment plants act as a potential point source of microplastics? Preliminary study in the coastal Gulf of Finland, Baltic Sea. Water Sci. Technol. 2015, 72, 1495-1504. [CrossRef] [PubMed]

64. McCormick, A.; Hoellein, T.J.; Mason, S.A.; Schluep, J.; Kelly, J.J. Microplastic is an abundant and distinct microbial habitat in an urban river. Environ. Sci. Technol. 2014, 48, 11863-11871. [CrossRef] [PubMed]

65. Murphy, F.; Ewins, C.; Carbonnier, F.; Quinn, B. Wastewater treatment works (WwTW) as a source of microplastics in the aquatic environment. Environ. Sci. Technol. 2016, 50, 5800-5808. [CrossRef] 
66. Ziajahromi, S.; Neale, P.A.; Leusch, F.D.L. Wastewater treatment plant effluent as a source of microplastics: Review of the fate, chemical interactions and potential risks to aquatic organisms. Water Sci. Technol. 2016, 74, 2253-2269. [CrossRef]

67. Kemerovo Region Investment Passport. 2018. Available online: https://keminvest.ru/media/W1siZiIsIjIwMTkvMDgvMjUvNWM5 N2V0cG05X2t1emJhc3NfaW52ZXN0cGFzc3BvcnRfMjAxOF9lbmdsaXNoXzZfaW5ldC5wZGYiXV0/kuzbass_investpassport_2018 _english_6_inet.pdf?sha=18184cf401373917 (accessed on 7 November 2020).

68. Habib, D.; Locke, D.C.; Cannone, L.J. Synthetic fibers as indicators of municipal sewage sludge, sludge products, and sewage treatment plant effluents. Water Air Soil Pollut. 1998, 103, 1-8. [CrossRef]

69. Zubris, K.A.V.; Richards, B.K. Synthetic fibers as an indicator of land application of sludge. Environ. Pollut. 2005, 138, 201-211. [CrossRef]

70. Ziajahromi, S.; Neale, P.A.; Rintoul, L.; Leusch, F.D.L. Wastewater treatment plants as a pathway for microplastics: Development of a new approach to sample wastewater-based microplastics. Water Res. 2017, 112, 93-99. [CrossRef]

71. Fendell, L.S.; Sewell, M.A. Contributing to marine pollution by washing your face: Microplastics in facial cleansers. Mar. Pollut. Bull. 2009, 58, 1225-1228. [CrossRef]

72. Siegfried, M.; Koelmans, A.A.; Besseling, E.; Kroeze, C. Export of microplastics from land to sea. A modelling approach. Water Res. 2017, 127, 249-257. [CrossRef]

73. Dris, R.; Gasperi, J.; Saad, M.; Mirande, C.; Tassin, B. Synthetic fibers in atmospheric fallout: A source of microplastics in the environment? Mar. Pollut. Bull. 2016, 104, 290-293. [CrossRef] [PubMed]

74. Isobe, A. Percentage of microbeads in pelagic microplastics within Japanese coastal waters. Mar. Pollut. Bull. 2016, 110, 432-437. [CrossRef] [PubMed]

75. Tanaka, K.; Takada, H. Microplastic fragments and microbeads in digestive tracts of planktivorous fish from urban coastal waters. Sci. Rep. 2016, 6, 1-8. [CrossRef] [PubMed]

76. Klein, S.; Worch, E.; Knepper, T.P. Occurrence and spatial distribution of microplastics in river shore sediments of the Rhine-Main Area in Germany. Environ. Sci. Technol. 2015, 49, 6070-6076. [CrossRef] [PubMed] 